DOI https://doi.org/10.36059/978-966-397-225-1-3

\title{
THUMPING VICTORIES OF THE MICROCOSM
}

\section{Korniienko Nelli}

\section{INTRODUCTION}

The cultural development of humanity, experiencing the transition from modernity to post (post) modernity, strengthens the trajectory of the socalled interpretive mind and prefers the communicative functions of culture. Now communication becomes one of the core values. The focus is on the Others. The categories of "general", "suprapersonal absolutes", "unified truth" give way to the categories of "special", "unique", private, detailed, internal imperative, and decanonical.

Henceforth the path to a possible integral experience of the Universe presupposes a new quality of relations with the "unique" and new ethics concerning values. It requires neutralisation of previous myths.

That's why matters that had no actual significance until recently become a prerequisite for integrity. Culture expands the horizon of the concept of the $I$ to the formula I-with-my inward that is both visible and invisible and the Universe, where any detail according to its peculiar metonymic principle can maintain its integrity or restore in case of damage, and where there are no rigid hierarchies. Everything is essential, and one can't do without it. Momentariness speaks Faust's language.

The thumping victories of the microcosm: particles, artistic nuances and details, nanotechnologies - have distinguished new frontiers of scientific focus. The self-organisation theory and synergetics concentrate their efforts on unravelling the mechanisms of self-organisation, namely on these microscales. It also concerns the humanities, above all, indeed. The resistance which is experienced for the umpteenth time in the history of science by the efforts to adapt the leading creative natural science methodologies to the humanitarian field is evidence of both the complexity of the tasks and the general conservatism and the lack of an adequate language of communication between "physicists" and "lyricists", that has also been repeatedly discussed.

The answer to the question "why is there such an interest in detail in art culture today?" is that the direction mentioned above has success in its foundations. In the humanitarian sense, it is an increase in attention to particular phenomena and microphenomena and marginal states, and 
therefore an increase in the status of altruism. In the experimental Logos, it is a stop at the deepest and the most subtle of the hidden.

\section{Convergence of the Trajectories of Science and Art Culture}

Today one of the most exciting trends in art culture is total attention to the smallest detail, to fleeting states, invisibilities, coincidences, hidden movements, "impossible" or "unnecessary" until recently. Moreover, now it is namely the principal capital of current literary texts (semiotic).

This is the way the actor and author Yevhen Hryshkovets builds his stage text, providing this focal point. The space and time of his monodramas are permeated with increased attention to the smallest details. This gifts "stopping the moment" to the stories. The remarks serve for the same in his monodramas: "here it is necessary to take off shoes and show how big butterflies fly".

He manages to immerse us in the flow of life, in which someone else (his hero's) and yours seem to be mutually transformed, intimated, giving almost existential features to the new experience here and now. At these levels, we have a ubiquitous emotional and mental experience. The algorithms of life are realised through identity. An essential aspect of the stage behaviour of Hryshkovets' hero and his author is the creation "in the mode of equal presence" (S. Honcharova-Hrabovska). A life that has been seen "in six eyes" by the author, the hero, and the spectator, equal within the existential coordinates gives Hryshkovets' stories a peculiar effect of semantic animation.

Taras Prokhasko, in his book of essays Port Frankivsk, which critics neatly called "the saga of local metaphysical lore", passes the Universe through the sacred landscapes of the native Carpathians. As for Bradbury, for him, the Universe depends on the slightest movement within it, on the involuntary shift of detail, on the "whims" of transience. Prokhasko is a natural synergetic who works at the intersection of the humanities and the natural sciences (it is no coincidence that he holds a degree in biology). His sensitivity to detail and to that what synergetics defines as small fluctuations that are known to be able to shift the flow of Being are sometimes striking. The feeling of the formula "everything in all" is arranged by the prose writer Prokhasko with a refined intellectual irony, to which the tragedy of his space is subdued. Before us, in the "genre" of the historiography of the small homeland, a picture of the domination of existence through its hidden, secret "language" unfolds. Involuntarily, the well-known fact is recalled: "the domination of things is characterised by the desire to hide". Prokhasko 
listens to the toponymy of the region, knowing this truth. And therefore its deep meanings acquire the sacred status.

Now the work of composer Valentyn Sylvestrov is emphasised by the aesthetics of innovation, based on a special trust in the "unknowable" and shaky, elusive. It tends to a new risk. The choral works appeared in his works. They are Liturgical Hymns. He insists that Byzantine monodies are a "solid ground" and that a voice hovers over it like a fire. "I build everything on a melody. But here the ground does not just exist; it lives. It is not solid; it also seems to flicker. This is not exactly polyphony, but a new form: chorales under the guise of monody. Except for the usual harmony, there are also acoustic harmony and temporal ones. Time does not move rhythmically; it is shaky as well". ${ }^{35}$

The composer is open to new dimensions in an attempt to "capture" them. Sylvestrov's search comes to a new "fundamental event" - a nuance, a subtext that has moved to other areas of stay. The shadows, flicker of energies, "barely" are becoming the foundation of modern complexity now. Sylvestrov deeps into the personal, into the private intonation, into the area of the heart based on not so "flat" sound as its unbalanced states, which acquire new energies due to sound inflows and the already mentioned flicker. The "quanta", the microparticles of wave energy, flicker.

Valentyn Sylvestrov 's The Quiet Music for the String Orchestra (2002) reaches such a degree of lightness that it seems that it is the flicker of the air itself, as in the case of Arkhypenko's sculptures. And modern 2012 recordings of his Bagatelles (2005) in the studio led to the need for special exercises with the technique of sound recording to reproducing adequate "particles-details" of sound.

The examples mentioned above establish a mirror-asymmetric relationship with the role of fluctuation, the smallest exciter of vibrant energy, and its modern version.

Culture reminds the repeatability of a similar formula inversely, already reproduced in another historical time (mind the philosophers and culturologists, at least Batkin and Bibler, who wrote about the re-existence of artistic styles). When H. Wölfflin tried to "test" the previous Renaissance art systems according to Baroque criteria, the Renaissance law of absolute unity of all parts of the text, the absolute necessity of a particle in it was opened: both beauty and sense of the whole would collapse at the moment when any creative (or expressive) smallness would be damaged ${ }^{36}$.

${ }^{35}$ Sylvestrov V. (2006, June 23) [Interview with the composer]. Kievskie vedomosti.

36 Wölfflin H. (2004) Renessans $i$ barokko [Renaissance and Baroque] (trans. Lundberg E., ed. Kozina E. N.). St. Petersburg: Azbuka-klassika. 
The theatre diagnoses a new state of artistic consciousness: one of its interests is beginning to realise, as everywhere, the value of "micro", "nano" - a microcosm, small event, psychological microstate, the smallest detail - intonation, micropause, micro-silence - either in the actor's stay on the stage, or in a musical phrase, or a short brush stroke. The viewer's eye approaches the microscope. The ear is to feel the frequencies in the involuntary movement that it has not known before, to reproduce the archaic "models" of hearing when a person was still able to hear nature thinner, was "inseparable" from it, even animal; but, perhaps, the modern ear learns new acoustic energies after they have been felt and reproduced by the pioneers.

One thing is indisputable: we are looking into the world of "artistic microparticles", and artistic "nanos". They are reflected in our minds as nanosubjects. Internal spaces are involved in the act of reconsidering the concept of their completeness.

The weapon of a microparticle is the fundamental otherness of the laws of its environment, and therefore of its behaviour. There is no need to remind us that the world is one, and everything is in all. The modern natural sciences, which, we want to think so, moves towards the humanities, knows this as no one else. Their current dialogue gives existence to the entirely different artistic revelations, confessions, meanings and forms as the pictures of the world. The existence in the Other transforms the notion of identification radically.

We consider it will not be unfounded to turn to the inexorable ways of the already mentioned unity. After all, the very life of the smallest particles has changed the fundamental scientific logic of the Universe. It has changed the concept of time, space, law, accuracy, and calculus. The second beginning of thermodynamics, as it's known, "abolished" the concepts of rigid regularity, order, certainty, and a unified truth. The whole chain of these transformations carried out by the scientists and thinkers - from Saint Augustine to Galilei and Newton, from Leibniz and Hamilton and to A. Einstein, Planck and Eddington - illustrated modern non-classical and post-non-classical ideas about the construction of the Universe, and, the most important and what we are interested in, - about the microcosm, the uniqueness of its "inner space". Getting free from faded dimensions, physics accumulated paradoxes. But moving through them zealously, it experienced the priceless experience. In particular, in relations with the microcosm.

There are questions. Can half of an apple weigh more than a whole apple? Can "an elephant get into a pan"? Can the mass of the smallest of the currently 
discovered particles, the quark ${ }^{37}$, exceed the mass of a proton, which consists of three quarks? In the world of microparticles (in the world of details, nuances) these questions lose not only their paradox but also meaning. ${ }^{38}$ In the microcosm, the laws of the macrocosm do not work (with which we mostly deal with). And there a half of an apple weighs more than the whole one, and the elephant is happy to make himself comfortable in a pan.

The aesthetic practice of modern theatre and cinema draws our attention to the reconsideration of the leading aesthetic concepts - beautiful and ugly. Marc Caro (worked in tandem with Jeunet) in his films Delicatessen (black comedy-Guignol, with a crazy Pierrot in the centre) and especially in The City of Lost Children (surrealism and cruel fiction), full of intellectual humour and dramatic suspense at the same time, anxious sensuality, deliberately introduce an image of the dark as a mandatory, working on the alienation of the fantastic, strange: the film Dante 01 presents his science fiction reflections (a film about a space prison).

Caro claims that without the mixing of light and dark, yin and yang, nothing can happen because there is no notable difference between light and dark. They hold each other. In Caro and Jeunet's films, the shape and colour always have a symbolic function, like a tattoo. The aesthetics of the ugly, as these French directors interpret it, is primarily based on the attention to the deep inner.

All formal and aesthetic tools: human characters, the film atmosphere, its moods build a symbolic and fantastic component. As a rule, this layer is based on the unusual (ugly) face, which is also "destroyed" by wide-angle lenses (there is an opinion that the works of Caro, who drew comics, also played their role), on the curvature of gestures, on an unusual camera movement that "confirms" the shift of the portrait towards non-canonicity. This shift is non-classics. The characters respond with status marginality. He and She. Love. Spiritual orphanhood. They are finding each other. Yin and yang feel unembodied before "mixing" uniting.

Implied by the text of the films, the reconsideration of the notion of the not good looking, ugly as evil (in the Christian tradition - the consequence of the Fall), moves as if in inversion "repetition". It is well-known that "based on the opposition of the spiritual and the corporeal in the Middle Ages, it was believed that an unattractive and even ugly appearance could be combined with internal (mental or spiritual) beauty. In the system of patristic symbolism, the shameful, "worth of outrage" appearance of the crucified

${ }^{37}$ A quark is a hypothetical particle that has not yet been detected in the experiment, but physicists consider it the "primary cell" of the universe

${ }^{38}$ Zyhunenko S. (1991) Kak ustroena mashina vremeni? [How is the time machine built?]. Moscow: Znanie. (Seriya "Znak voprosa”; no. 5). 
Christ becomes a symbol of his unspeakable divine beauty. The ugly has been given a symbolic function since patristic times. Dionysius, the Areopagite claimed that God could be symbolised by even the most unattractive of things, such as a stone, a worm, etc." 39 .

Jean-Pierre Jeunet and Marc Caro appeal to the intellectual horizon of hope. It is an art-house or auteur cinema; another cinema. But in the sensuality of their films, the echo of shamanism is recognisable, and it is no coincidence that Caro admires this pagan language of communication which is now defined as mystical.

Tim Whitehead, the actor of the London cabaret and comedy theatre Soho Theatre, has an exciting experience on the same topic ${ }^{40}$. He explores the concept of beautiful and ugly deliberately; he is attracted by the mysteries of balancing between art and kitsch. Tim Whitehead introduces a new movement in the UK as an alternative cabaret and a unique project on beauty and ugliness ${ }^{41}$. He is delighted with Jonny Woo, a drag queen with a beard who reads rap, with the performer Scottee. He is attracted to ancient national "performances" such as the Day of the Dead in Mexico ${ }^{42}$ when the theme of death is touched by the boldness of the views and humour.

Whitehead loads the category of beauty, which, he believes, can be found everywhere, with moral qualities first of all: decency, trust, doing no evil to others, tenderness, the desire to seek beauty, the non-pursuit of success at any cost, humour. He perceives the logic of the cruelty of Nan Goldin's photos with drug addiction and prostitution justifying the shock with the tenderness with which these painful plots have been taken. The sequence of his views is also expressed in the "freak show" of The Tiger Lillies band, in which people are considered as freaks: Whitehead loves them for "beautiful hearts and a great sense of humour", they are just others, extraordinary, beautiful and splendid, strong and fun they are free.

Now the concept of beauty in the interpretation of art culture is once again evolving to the spiritual equivalent of the concepts of ethics and morality, the qualities of forgotten altruism and charity. It develops unpragmatic, unselfish values. There is the change of the canon, the break of standards that lead to a new understanding of corporeality, truth and beauty.

${ }^{39}$ Petrushenko V. L., Surmai I. M., Karvatska H. F., Mazur L. I., Shadskykh Yu. H. (2008) Etyka ta estetyka [Ethics and aesthetics] (ed. Petrushenko V. L.). Lviv: Lviv Polytechnic National University.

${ }^{40}$ Pogodina L. (2011) Gadkie lebedi i tigrovye lilii [Ugly swans and tiger lilies]. SHO, no. 1-2(63-64).

${ }^{41}$ www.bourgeoisandmaurice.co.uk

${ }^{42} \mathrm{http}: / /$ zateevo.ru/?section=page\&action=edit\&alias=den_mertvih 
This is how not only cinema or theatre works in their search zones (we have already written about a kind of theatre of cruelty in the Ukrainian Zholdak, the Italian Castellucci or the German Castorf - so now we will not labour the point).

We mean an interesting precedent in the popular performance field. The Suka Off band ${ }^{43}$ (Concept by Piotr Wegrzynski and Sylvia Lajbig) works in theatres, galleries, and fetish clubs. They intended to create an independent visual theatre that would reproduce various genres and performances, and club shows, and body art. The most interesting was the experiment with the taboo ideas; that's why the shock was an objective accompaniment to their performances. And as a result, the band has become a constant target of tabloid interest. It is accused of indecent shocking of a decent audience, pornography, disrespect for viewers.

But the group itself demonstrates a desire to talk about the virus of violence and speak at, say, the "atomic-molecular" or nano scale. They even have the term "liquid inspiration". We quote the ideologists: "The liquid as a whole inspires us. We use it in many ways, both synthetic liquids and biological ones, such as our blood. The loss, absorbing or mixing of liquids is very often a key point in our performances. Characters drink them, inject them, spit them out, vomit them out, spew them out in every possible way; they bleed them. All of them are containers and vessels. Like in a lab, adding or removing ingredients, you getdifferent results, different emotional states, different behaviour, different status" ${ }^{\prime 4}$. The symbolic properties of the band's performances, such as TranSfera or Red Dragon, appeal to hidden meanings and are caused by the need to reconsider the values of life. It was because of the sentence cruelty. Because of the technology of alienation from the stereotype, life is perceived mainly in its usual social or domestic and psychological dimension.

The performances with bloodletting and hanging on hooks, with a paradoxically dramatic, rigid idea of "liquid inspiration" are a cause to think about the philosophy of Being, violence against the spirit, not-this-reality in reality.

The inversion movements of art culture continue to "pull" deeper and deeper contexts for the interpretation of modern intellectual and spiritual values; for their reconstruction outside of binary schemes. The latter is crucial.

Art culture deepens its mediation resource. But such performances force the humanities, in particular, art critics and theatre critics, to stop at the essential solution of new knowledge about liquid spheres. There are secrets

\footnotetext{
${ }^{43}$ http://www.sukaoff.com/

${ }^{44}$ Luzhetskiy P. (2010) Teatr zhestokosti [Theater of cruelty]. SHO, no. 1-2(51-52).
} 
that can offer art, and especially theatre, the person in it, the actor, in particular, the possibility of a new language.

I was suddenly struck by a spontaneous correlation between the search for the mentioned scandalous band with its "liquid inspiration" and the latest investigations by the scientists working with DNA and also liquid (water). Their researches are equivalent to some kind of post-fantastic scientific syndrome.

Luc Montagnier, the winner of the 2008 Nobel Prize (his discovery of the human immunodeficiency virus), has managed to make a discovery that, in our opinion, is equal to the Big Bang. He claims: "there is every reason to consider that DNA is able to send "imaginary" electromagnetic imprints of itself to distant cells and fluids. And enzymes can mistakenly take these imprints for real DNA and start copying them to reproduce the original".

In fact, this is quantum DNA teleportation, according to New Scientist. Montagnier's research team has proved that DNA emits low-frequency electromagnetic waves that reflect the structure of a molecule in water. This structure is protected and enhanced by the action of quantum coherence. And because it replicates the original DNA, enzymes... take it for the real one and use it as a template to make the DNA similar to the one that has sent the signal.

How to believe in it? Does nature (or Creator) suggest the right to indepth reproductions of human and being, the possibility of some new anthropic recombinations? Is an experiment with hitherto unknown properties of DNA and unknown programs for its translation - proposed?

The witnessed fact of "quantum teleportation" is vital to us. Because it can become an energetic, "quantum" material (or is it such one, and we only unravel it) to create artistic and aesthetic matters, an image, "verbal symphonies, equivalent to silence" (according to Sartre), unpredictable forms of silence, associations, metaphors, a new gesture, a new relationship with the subject... new ecological state of mind, new spiritual energy.

It is difficult even to imagine the possibility of such an unpredictable human existence. And first of all, of a human-actor as a pilot designer of this world.

We incline to view peculiar "nanotechnology" from the arsenal of the theatre of cruelty, shocking theatre (isn't it time to remember the "laws" of the $\boldsymbol{K}$-meson and the microcosm?) not as a manifestation of disrespect for the audience, cynicism or disregard for ethical traditions, as critics consider, but as guessed by predicting (heuristic), self-regulation programs experiment of theatre and art culture on spontaneous synchronisation with natural science experiments. This is a peculiar formula for mutual discoveriesconfirmations, the convergence of the trajectories of science and culture. 
It is namely the processes of such synchronisation through culture (art culture) that ensure the efficiency and integrity of the Being of ethnic groups, societies and communities.

\section{Artistic Theory of Relativity: Creating Pillars}

Mind the ancient insights of the creative mind about the evolution of individual abilities. In particular, it regards the possibilities of its penetration into the inner worlds, into the "invisible", into subtle matters, most attested by Eastern philosophies and practices. We often use these categories as a kind of metaphor because art has given us a sense of the reality of this "invisible".

Meanwhile, modern technologies and methodologies allow us to "see" and record fundamentally new levels of freedom for all subjects of the evolutionary process. These "freedoms" are open to the Universe. Individuality is built up by "openness" to universalisation, which, thus, implies a movement towards spiritual principles that are the only isomorphic to the "invisible". The high levels of freedom of nonlinear systems (humans, animals, artistic systems, social systems, etc.), now attested, simultaneously mean high levels of their self-sufficiency, independence the right to make independent decisions, implement their life scenarios, and do not depend on the environment created by causal relationships in their behaviour. (By the way, the indirect argument in favour of the law of independence is the too independent role of film and video technologies - art technologies).

The law of independence of art systems was periodically emphasised by history (we have proposed this name of the law for its introduction into scientific use). Let me remind you of something well-known.

The terrible economic shrinking in Italy in the 16th century did not prevent the creation of the masterpieces by Leonardo, Michelangelo, and Raphael, the latter relied on laws inherent only in art systems that compete in accuracy with the laws of Physics, Chemistry, Biology. And they are nonlinear. A similar situation is observed in Spain in the 17th century, which in the conditions of a deep economic crisis has created its high spiritual texts, having enriched world culture with them. The same can be said of Germany, which was destroyed by the 30 -year war (the 17th century), which lost two-thirds of its population when J.S. Bach was displayed for the world.

It's not worth remembering Rublev's times in Russia. H. Pomerants wrote about all these facts but in a completely different context and on another occasion. We can continue the list with Ukrainian realities: Stefanyk, Kotsiubynskyi, Lesia Ukrainka, Franko, Les Kurbas, Arkhypenko, the high artistic and musical avant-garde took place during the "death" era of the First 
World War, the October Revolution and further repressions of Ukrainian culture. The same can be said about the Russian culture of this era.

In our long-term study of the levels of freedoms of artistic culture, back in the early 1970s, we "discovered" the law of independence of artistic culture on the example of the functioning of the theatre, which resulted in several monographs ${ }^{45}$.

The study of creative scenarios of the theatre as a subject of Being, as an artistic and communicative system with high degrees of freedom, will give impetus to a new dialogue between the theatre and society. And in particular, the activities of the theatre on the formation of civil society and its "democratic projects": we have already had the opportunity to talk about the role of theatre (art culture) in such a significant process of the life of society as the removal of totality, otherwise - the separation of Siamese twins - state and society ${ }^{46}$.

The law of independence of art systems in our context is the symmetrical concept of artistic theory of relativity. The creation of its pillars is the work for a whole generation of scientists and requires the involvement of effective idea generators.

Some artists discovered the mentioned theory of relativity in art: in poetry, they are Apollinaire and Rimbaud, in the fine arts - Picasso, Matisse, Braque, Kandinsky, Malevich, Ekster, Tatlin, in the theatre - Les Kurbas, Artaud, Meyerhold, in sculpture - Arkhypenko - all they became "Einsteins". Now, this movement continues.

Arkhypenko breaks finally with the laws of classical sculpture, even then expanding the "genre" to sculptural painting. Having violated traditional canons, he has subjugated the statue to the laws of music and poetry, creating new formulas of colour sound. His plastic figures argued with the usual "reality",

45 Korniienko N. (1986) Teatr segodnya - teatr zavtra. [Theatre today - Theatre tomorrow]. Kyiv: Mystetstvo; Korniienko N. (1998) Les Kurbas: repetytsiia maibutnoho [Les Kurbas: Rehearsal of the Future]. Kyiv: Fakt; Korniienko N. (2007) Les Kurbas. Kyiv: Lybid.

Korniienko N. (1993) Teatr yak diahnostychna model suspilstva. Deiaki universalni mekhanizmy samoorhanizatsii khudozhnoi kultury [Theatre as a diagnostic model of society. Some universal mechanisms of self-organisation of art culture] (Abstract of DSc Dissertation). Kyiv: Rylsky Institute of Art Studies, Folklore and Ethnology of National Academy of Sciences Ukraine.

${ }^{46}$ Korniienko N. (1992) Kultura: perekhodova doba i nezalezhna derzhava [Culture: the transition period and an independent state]. Slovo $i$ chas [Word and time], no. 2, pp. 29-32.

Korniienko N. (1994) Ukrainska kultura v konteksti derzhavotvorennia [Ukrainian culture in the context of the state creation]. Proceedings of the Ukrainoznavstvo $v$ rozbudovi derzhavy: Materialy shchorichnoi mizhnarodnoi naukovo-praktychnoi konferentsii (Kyiv, Ukraine, October 14-16, 1994), Kyiv: Instytut ukrainoznavstva.; et al. 
with the idea of three-dimensional space. New dimensions of the air itself, visible and invisible in it, materialised. The sculptures often resemble "flashes" of the ether, the explosion of "quanta", barely perceptible airwaves (Woman Combing Her Hair, 1915). The moment of the flash obeyed Arkhypenko. It is no coincidence that the master valued "absence" so much.

Critics insist on "mystical intangibility, on a new spatial dimension": "His sculpture, abstract and surreal, which is already cramped within the framework of fine arts, has absorbed the uncomplicated childish worldview of Africa, the fascinating antiquity of Trypillia culture, mysterious ecstasy, the sophistication of Pythagorean Hellas, the cosmism of ancient Egyptian sun worship, the influence of the mysterious and silent East" (Andrii Shestakov).

On the ways of creation of a new language of culture, art - in particular, theatre - does not just cross the boundaries of its identity, marking other people's territories as its own. It makes an impressively complex research experiment: it artistically and mathematically models aesthetic reality not according to the already known laws of its components, but according to new, probabilistic, some "alchemical" conventions, which still need to be studied.

In February 2011, the Robin Howard Dance Theatre in London hosted the international premiere of the dance interpretation of Kazimir Malevich's painting Black Square, starring the lead soloist of the Royal Ballet Edward Watson $^{47}$.

The choreographer of the play, Mr Burlov, notes: "If we take the Black Square and the date of its creation as a starting point and think about the planet against the background of the square, we will see a technological boom, imbalance and diversion from the true path. Now all that remains is to offer the planet that came to the last cry". ${ }^{48}$ "In general, Burlov's choreography, figuratively speaking, is "neuro-paralytic", which denies any classicism... It is needless to remind that the choreographer works in the style of contemporary dance" ${ }^{, 49}$.

This creative experiment is based not so much on the aesthetic layer of the foundation as on the computer and mathematical game Life, invented by the British mathematician John Conway.

${ }^{47}$ Choreographer Kirill Burlov (Riga Ballet School); visual design of the stage belongs to the "virtual reality theatre" alKamie; costume designer Aigan Gali; musicAnneli Nederberg, Sweden.

48 Shavrei A. (2011) Rizhskaya khoreografiya dlya zvezdy Kovent-Garden [Riga choreography for the Covent Garden star]. LifeNews. Retrived from: http://www.lifenews.lv/news/rizhskaya-horeografiya-dlya-zvezdy-kovent-garden

(accessed 15 October 2020)

${ }^{49}$ Ibid 
The fantastic interpretation of life in itself - in the form of a game through the laws of evolution of the geometry of "living" black cells strikes with its unusualness, especially when it comes to the 1970s. But now to adapt the artistic and aesthetic matters of the most extreme example of the descriptive avant-garde to stage plasticity on the basis of the ideas of computer mathematics - for this you really need to be a poet and a scientist, a team of, for example, poet-scientists at the same time! Indeed, the intersection of concrete and abstract sounds, vocal music and noise, electronics and traditional music creates exactly the poetic formula of space, which, as the composer admits, has been its intention.

We emphasise once again that starting with the modernist-innovatorsavant-gardist, theatre and artistic culture in the process of self-regulation causes unexpected explosions of artistic configurations from their depths, which testified to an unknown yet experience. "Traces" of laws were clearly projected on the surface. The secret of the avant-garde, as it has finally become clear now, was precisely in the promulgation and making present by artistic means of laws, in particular, laws of sub(beyond) conscious ${ }^{50}$. Those are hidden.

In our monograph on Chaos (2007), we state that art culture has its laws that are preconceived against academic science, as well as its strategies and programs, and today it completes the compilation of the artistic theory of relativity $^{51}$. That is, not only the avant-garde, from our point of view, has reached the depths of the fundamental laws of art. It's just that the search areas, to which the avant-garde undoubtedly belongs, are more sensitive to any internal processes in the system, and they are often tightly hidden. They are implicit ${ }^{52}$.

S. Žemaitis considers that his discovery "in the field of the theory of relativity of space and time, computer technology and informatics, genetic codes, higher nervous activity, the theory of consciousness, telecommunications, astronomy, the Internet, quantum mechanics, several

\footnotetext{
${ }^{50}$ This, in particular, is stated by a modern researcher of the avant-garde, in particular, the works of Malevich, Kandinsky, Tatlin, Filonov-S. S. Zhemaitis.

51 Korniienko N. (2010) Zaproshennia do khaosu. Teatr (khudozhnia kultura) $i$ synerhetyka. Sproba neliniinosti [Invitation to chaos. Theater (art culture) and synergetics. Attempt at nonlinearity] (2nd ed.). Kyiv: Les Kurbas National centre for theatrical art.

${ }^{52}$ We do not rule out that we are talking about what the famous innovative physicist, Einstein's best student David Bohm, based on the holographic theory of the universe, called "the deep Order of being", and this "deep level of reality" called "implicative (i.e. hidden) order", as opposed to "explicative, or open order"
} 
other significant areas that defined the face of the 20th century...", and allowed to find the subject and object of the avant-garde ${ }^{53}$.

He writes: "The founders of the avant-garde called this art objectless. That is, they meant that there is some invisible object somewhere near us that transmits information, images, models of some still incomprehensible, or not completely clear in their structures to them. Today we have grounds to assume that the objectless object, which was observed by the representatives of the avant-garde, is nothing else but our consciousness in that part of it, which is called the Unconscious. Avant-gardists, in contrast to the representatives of real trends in art, has switched to the internal process of contemplating the work of our brain and brought some aspects of the unconscious to the level of the conscious"

Further, based on the ideas of Kandinsky, who stated that "all his works use the principles of information coding" and even "before the discovery of digital information transmission, stated that colour, space and time can be transmitted using codes" figurative avant-garde was a form of "prophetic" futurological art.

"We can assume that consciousness often does not invent anything, but takes it ready-made from its "floors". That is, here we deal with the ability of human consciousness to receive images of the future. Starting from the works in this area, as well as works in the field of architecture of consciousness, we can assume that in our brain, as in microcosm, there are really analogues of processes that already exist in the macrocosm"56, - says Žemaitis.

And it draws our attention to $\mathrm{V}$. Kandinsky brilliant conjecture that space and time are created by our consciousness. And then, as if following the path of our hypotheses about the ultra-high autonomy of artistic systems and their biased (and not just initiating) strategies, suddenly, from a different point of view, from the horizon of completely different interests-this leading strategy confirms: "this largely implies the theory of the creation of space and time from a single field located in the Universe. That theory, which was born much later, in the depths of quantum physics and the works by A. Einstein and N. Bohr" ${ }^{, 57}$.

53 Žemaitis S. (2010) Avangard i arkhitektura soznaniya [Avangard and architecture of consciousness]. Proceedings of the Iskusstvo posle filosofii:. vserossiyskaya konferentsiya (Russia, St. Petersburg, Nowember 20-21, 2009), St. Petersburg: SanktPeterburgskoe filosofskoe obshchestvo.
${ }^{54}$ Ibid
${ }^{55} \mathrm{Ibid}$
${ }^{56}$ Ibid
${ }^{57}$ Ibid 
The experience of the avant-garde, so to speak, helps to "make transparent" the heuristic lines of dialogue between modern and afterpostmodern, between classics and post-non-classics, archaic and contemporary. The origins of the similarity of the avant-gardists' works with the objects of the micro- and macrocosm: "cellular, genetic structures, as well as galaxies, nebulae, star clusters", in particular, in Kandynskyi (S. Žemaitis), are in the presence of their models in the artist's mind. The invisible a priori reveals the "need" to transform into the reality of Being. The hidden model of consciousness (beyond the conscious) encodes the one that is supposed to be embodied on canvas, screen, or stage artistically. In fact, consciousness plays the role of a kind of "medium", repeater, "seller" of codes. According to this scheme, the avant-garde materialised the "ideas" of the unconscious on canvases.

Kandinsky, the artist-researcher is an innovative subject, the type of which we wrote about in connection with the theatre - surpassed future artistic and technological models of the new reality. This example of a proactive artistic strategy confirms once again the degree of independence, subjectivity, will of art.

So, we have the evidence of the presence of the "future" in the artistic space, an innovative subject that will continue to create the artistic theory of relativity and which still make only post-non-classical horizons present.

\section{CONCLUSIONS}

Contemporary world art culture, being a consequence of the development of previous cultural traditions, having absorbed their features, also has the specific properties that give it originality and uniqueness. Therefore, it should be considered comprehensively in interrelation with various factors and aspects of life. The artistic space is closely connected with all current processes that not only affect it but also undergo changes. Sometimes scientific achievements, in particular fundamental theories, relativity theories, often go far beyond their science and influence not only on related sciences but also on philosophy, the humanities and even art culture.

One of the features of modernity is a change in the very model of cognition. There is a reason to claim that there is a gradual rejection of the traditional focus on knowledge and the transition to the information model. The knowledge is focused not only on the use but also on understanding and involvement in the situation. The present model of information is more relevant to urgent needs and trends because the information can be transmitted into a single code system without distortion, and therefore used, transmitted and preserved. 
The genesis of culture and human activity, which causes deepening of the world of human needs, the growth of the human factor are laws of development for the artistic needs of the individual. This means that artistic need as personal education must be considered in its connection with catharsis and its mechanisms, and self-actualisation of the individual as well. Art forms the spiritual world of a person, person's ideological and moral beliefs, determines the system of values of the individual.

After all, the phenomenon of crisis in culture is a mandatory and natural stage. Crisis moments in culture indicate its exhaustion, the need to reassess all values. However, new values are only at the stage of formation, so the crisis can be seen as a transitional period necessary to develop new guidelines. Crisis situations contribute to the emergence of preconditions for the development of a new culture or accelerate the collapse of an existing culture. Thus, we have evidence of the presence of the "future" in the artistic space, an innovative subject that will continue to create the artistic theory of relativity and which still make only post-non-classical horizons present.

\section{SUMMARY}

The cultural development of humanity, experiencing the transition from modernity to post (post) modernity, strengthens the trajectory of the socalled interpretive mind and prefers the communicative functions of culture. Now communication becomes one of the core values. The focus is on the Others. The categories of "general", "suprapersonal absolutes", "unified truth" give way to the categories of "special", "unique", private, detailed, internal imperative, and decanonical. The purpose of the article is to study a new level of artistic and emotional needs in contemporary European societies, which develops programs of attention to the special, "small", unique, phenomenal things. It is these social values that are now diagnosed by culture as a deficit. We have shown the urgent need to strengthen and build up humanistic and altruistic humanitarian projects. The scientific novelty is determined by the fact that the research deepens the idea and reveals the essence of the relationship between art and science, since this connection contributes not only to the enrichment of industries but also to social progress in general complements and develops pictures of the world, forms the environment, opens up new frontiers of development. Conclusions. The artistic space is closely connected with all current processes that not only affect it but also undergo changes. Sometimes scientific achievements, in particular fundamental theories, relativity theories, often go far beyond their science and influence not only on related sciences but also on philosophy, the humanities and even art culture. The genesis of culture and human activity, which causes deepening of the world 
of human needs, the growth of the human factor are laws of development for the artistic needs of the individual. This means that artistic need as personal education must be considered in its connection with catharsis and its mechanisms, and self-actualisation of the individual as well. Art forms the spiritual world of a person, person's ideological and moral beliefs, determines the system of values of the individual.

\section{REFERENCES}

1. Korniienko N. (1986) Teatr segodnya - teatr zavtra [Theatre today Theatre tomorrow]. Kyiv: Mystetstvo. (in Russian).

2. Korniienko N. (1992) Kultura: perekhodova doba i nezalezhna derzhava [Culture: the transition period and an independent state]. Slovo $i$ chas [Word and time], no. 2, pp. 29-32.

3. Korniienko N. (1993) Teatr yak diahnostychna model suspilstva. Deiaki universalni mekhanizmy samoorhanizatsii khudozhnoi kultury [Theatre as a diagnostic model of society. Some universal mechanisms of self-organisation of art culture] (Abstract of DSc Dissertation). Kyiv: Rylsky Institute of Art Studies, Folklore and Ethnology of National Academy of Sciences Ukraine.

4. Korniienko N. (1998) Les Kurbas: repetytsiia maibutnoho [Les Kurbas: Rehearsal of the Future]. Kyiv: Fakt. (in Ukrainian)

5. Korniienko N. (2007) Les Kurbas. Kyiv: Lybid. (in Ukrainian)

6. Korniienko N. (2010) Zaproshennia do khaosu. Teatr (khudozhnia kultura) $i$ synerhetyka. Sproba neliniinosti [Invitation to chaos. Theater (art culture) and synergetics. Attempt at nonlinearity] (2nd ed.). Kyiv: Les Kurbas National centre for theatrical art. (in Ukrainian)

7. Korniienko N. (1994) Ukrainska kultura v konteksti derzhavotvorennia [Ukrainian culture in the context of the state creation]. Proceedings of the Ukrainoznavstvo $v$ rozbudovi derzhavy: materialy shchorichnoi mizhnarodnoi naukovo-praktychnoi konferentsii (Kyiv, Ukraine, October 14-16, 1994), Kyiv: Instytut ukrainoznavstva.

8. Luzhetskiy P. (2010) Teatr zhestokosti [Theater of cruelty]. SHO, no. 1-2(51-52).

9. Petrushenko V. L., Surmai I. M., Karvatska H. F., Mazur L. I., Shadskykh Yu. H. (2008) Etyka ta estetyka [Ethics and aesthetics] (ed. Petrushenko V. L.). Lviv: Lviv Polytechnic National University. (in Ukrainian)

10. Pogodina L. (2011) Gadkie lebedi i tigrovye lilii [Ugly swans and tiger lilies]. SHO, no. 1-2(63-64)

11. Shavrei A. (2011) Rizhskaya khoreografiya dlya zvezdy KoventGarden [Riga choreography for the Covent Garden star]. LifeNews. 
Retrived from: http://www.lifenews.lv/news/rizhskaya-horeografiya-dlyazvezdy-kovent-garden (accessed 15 October 2020).

12. Sylvestrov V. (2006, June 23) [Interview with the composer]. Kievskie vedomosti.

13. Wölfflin H. (2004) Renessans i barokko [Renaissance and Baroque] (trans. Lundberg E., ed. Kozina E. N.). St. Petersburg: Azbuka-klassika. (in Russian)

14. Žemaitis S. (2010) Avangard i arkhitektura soznaniya [Avangard and architecture of consciousness]. Proceedings of the Iskusstvo posle filosofii:. vserossiyskaya konferentsiya (Russia, St. Petersburg, Nowember 20-21, 2009), St. Petersburg: Sankt-Peterburgskoe filosofskoe obshchestvo.

15. Zyhunenko S. (1991) Kak ustroena mashina vremeni? [How is the time machine built?]. Moscow: Znanie. (Seriya "Znak voprosa"; no. 5). (in Russian)

\section{Information about the author:}

Korniienko Nelli orcid.org/0000-0002-6894-6308

Doctor of Art Studies

Member of the National Academy of Sciences of Ukraine

National Centre of Theatrical Arts named for Les Kurbas

23-V, Volodymyrska St., Kyiv, 01034, Ukraine 